\title{
PREZENTACJE
}

Robert Jankowski

Zakład Historii Wychowania, Instytut Pedagogiki, Uniwersytet Szczeciński

Szczecin

\section{Dwudziestolecie Zakładu i Katedry Historii Wychowania w Uniwersytecie Szczecińskim (1992-2012)}

\begin{abstract}
The 20th anniversary of the establishment of the Department and Chair for the History of Education at the University of Szczecin (1992-2012)

The History of Education, one of the courses offered at teacher education studies at the University of Szczecin, has been taught since the 1960's. It was then when Teacher Education College in Szczecin was set up as a branch of Adam Mickiewicz University, Poznań. In 1973 Teacher Education College was transformed into an independent unit - Pedagogy Academy. The establishment of the University of Szczecin in 1985 marked a new chapter in the process of the development of the history of education as a course offered at pedagogical studies. History of Education Department was set up in 1992 and professor Danuta Koźmian was chair of the department throughout its existence. Scientific and didactic work of professor Danuta Koźmian first at Teacher Education College, through Pedagogy Academy and the University of Szczecin has been crucial for the development of the history of education as a course taught at teacher education studies in Szczecin. In 2008 professor Danuta Koźmian retired and the Council of the Faculty of Humanities at the University of Szczecin established the Chair for the History of Education appointing professor Wiesław Andrukowicz, Ph.D its head.
\end{abstract}

Keywords: the University of Szczecin, the Department and Chair for the History of Education, course: the History of Education at the University of Szczecin

\section{Geneza i rozwój Historii wychowania jako przedmiotu nauczania na studiach nauczycielskich w Szczecinie}

Historia wychowania jako jeden z przedmiotów nauczania w programie studiów nauczycielskich w szczecińskim ośrodku akademickim ma swój początek w latach sześćdziesiątych XX w. W tym czasie na podstawie Zarządzenia Ministra Oświaty i Szkolnictwa Wyższego z dnia 10 lipca 1968 r. powołano Wyższą Szkołę Nauczycielską 
w Szczecinie jako filię Uniwersytetu im. Adama Mickiewicza w Poznaniu. Uczelnia w dniu 3 października 1968 r. rozpoczęła kształcenie studentów na czterech wydziałach: Humanistycznym, Matematyczno-Przyrodniczym, Nauczania Początkowego i Wychowania Fizycznego.

Organizatorem Wydziału Nauczania Początkowego oraz jego dziekanem był docent doktor habilitowany Bolesław Sadaj, który kierował nim w latach 1968-1973. Prowadzono studia trzyletnie na dwóch kierunkach: Nauczanie początkowe z zajęciami praktyczno-technicznymi i Nauczanie początkowe z wychowaniem muzycznym. W ramach wydziału powołano cztery zakłady: Pedagogiki Ogólnej, Psychologii, Metodyki Nauczania Początkowego i Wychowania Muzycznego.

W roku 1970 w Zakładzie Pedagogiki Ogólnej w Wyższej Szkole Nauczycielskiej w Szczecinie rozpoczęła pracę jako wykładowca mgr Danuta Koźmian, absolwentka Wydziału Filozoficzno-Historycznego w Uniwersytecie im. Adama Mickiewicza w Poznaniu, której powierzono prowadzenie zajęć dydaktycznych z historii wychowania. Równocześnie z rozpoczęciem pracy w szkole wyższej mgr Danuta Koźmian zaczęła uczestniczyć w seminarium doktorskim prowadzonym przez Profesora Stanisława Michalskiego w Zakładzie Historii Wychowania Uniwersytetu im. Adama Mickiewicza w Poznaniu. Pod Jego kierunkiem napisała pracę doktorską na temat „Kształcenie i dokształcanie nauczycieli szkół podstawowych w województwie szczecińskim w latach 1945-1970" i w roku 1978 uzyskała stopień doktora nauk humanistycznych w zakresie pedagogiki. W tej samej uczelni zdała kolokwium habilitacyjne i w czerwcu 1992 r. otrzymała pierwszy w historii Wydziału Studiów Edukacyjnych Uniwersytetu im. Adama Mickiewicza w Poznaniu dyplom doktora habilitowanego. W 1994 r. Danuta Koźmian otrzymała tytuł profesora nadzwyczajnego, a w 2001 r. - tytuł profesora zwyczajnego.

Praca dydaktyczna i naukowa Pani Profesor Danuty Koźmian, od Wyższej Szkoły Nauczycielskiej poprzez Wyższą Szkołę Pedagogiczną do Uniwersytetu Szczecińskiego, miała zasadnicze znaczenie dla rozwoju historii wychowania jako przedmiotu nauczania na studiach nauczycielskich w ośrodku szczecińskim.

W dniu 1 października 1973 r. Wyższa Szkoła Nauczycielska została przekształcona w Wyższą Szkołę Pedagogiczną, samodzielną uczelnię podległą bezpośrednio Ministerstwu Nauki, Szkolnictwa Wyższego i Techniki ${ }^{1}$. Powołano cztery Wydziały: Humanistyczny, Pedagogiczny, Matematyczno-Przyrodniczy i Wychowania Fizycznego. W okresie 12 lat istnienia Wyższej Szkoły Pedagogicznej historia wychowania jako przedmiot w programie studiów pedagogicznych funkcjonowała w Zakładzie Pedagogiki Ogólnej na Wydziale Pedagogicznym, a osobą prowadzącą i odpowiedzialną za przedmiot była dr Danuta Koźmian. Warto dodać, że Wydział Pedagogiczny WSP w Szczecinie ukończyło 2628 studentów, którzy w większości trafili do szkół i placówek oświatowo-wychowawczych na Pomorzu Zachodnim z dyplomem magistra pedagogiki². W powojennej

\footnotetext{
1 Rozporządzenie Rady Ministrów z dnia 29 września 1973 roku w sprawie utworzenia Wyższej Szkoły Pedagogicznej w Szczecinie, Dz. Urz. Nr 39, poz. 231.

2 Archiwum Uniwersytetu Szczecińskiego, Absolwenci Wyższej Szkoły Pedagogicznej w latach 1974-1985 (obliczenia własne).
} 
historii oświaty zachodniopomorskiej ten fakt należy uznać za przełomowy w procesie kształcenia nauczycieli.

Powstanie Uniwersytetu Szczecińskiego w 1985 r. otworzyło nowy rozdział w procesie rozwoju historii wychowania jako przedmiotu na studiach pedagogicznych. W ramach Wydziału Pedagogicznego rozpoczął działalność Instytut Pedagogiki i Psychologii (obecnie Instytut Pedagogiki).

\section{Powstanie Zakładu Historii Wychowania i jego dorobek w latach 1992-2008}

Zakład Historii Wychowania funkcjonował w strukturze Instytutu Pedagogiki Uniwersytetu Szczecińskiego w latach 1992-2008. Został wyodrębniony z Zakładu Pedagogiki Ogólnej, a jego kierownikiem w całym okresie istnienia była Prof. zw. dr hab. Danuta Koźmian. Pracownikami Zakładu byli: dr Robert Jankowski, dr Ilona Kość i dr Elżbieta Magiera.

W zakresie pracy dydaktycznej w Zakładzie realizowane były zajęcia z następujących przedmiotów: historia wychowania, pedagogika porównawcza, podstawy prawne i organizacyjne oświaty oraz edukacja regionalna w kształceniu zintegrowanym. Ponadto prowadzone było seminarium magisterskie i doktorskie.

Profil naukowo-badawczy Zakładu Historii Wychowania koncentrował się wokół zagadnień historii oświaty i myśli pedagogicznej na przestrzeni dziejów, kierunków rozwoju szkolnictwa i koncepcji edukacyjnych na ziemiach polskich w okresie Drugiej Rzeczypospolitej, chrześcijańskiej myśli pedagogicznej oraz edukacji regionalnej. Dorobek wydawniczy Zakładu Historii Wychowania był bardzo bogaty i obejmował ponad 100 opublikowanych prac, w tym 16 indywidualnych monografii.

Problematyka badawcza, w której specjalizowała się Pani Profesor Danuta Koźmian była bardzo rozległa. Ważnym obszarem zainteresowań naukowych były zagadnienia dotyczące procesu kształcenia i dokształcania nauczycieli, co jest szczególnie widoczne w monografiach: Kształcenie $i$ dokształcanie nauczycieli szkót podstawowych $w$ województwie szczecińskim w latach 1945-1970 (Warszawa-Poznań 1986), Działalność Liceum Pedagogicznego imienia Adama Mickiewicza w Gorzowie Wielkopolskim w latach 1950-1970 (Gorzów Wielkopolski 2005), oraz w kilkunastu opublikowanych artykułach i rozprawach.

Wyraźnie zarysowanym nurtem działalności naukowej Profesor Danuty Koźmian są zagadnienia dotyczące oświaty, wychowania i doktryn pedagogicznych w Drugiej Rzeczypospolitej, co zostało uwidocznione w rozprawie habilitacyjnej pt. Samorzad uczniowski w polskiej pedagogice Drugiej Rzeczypospolitej (1918-1939) (Szczecin 1991), a także w kilku pracach monograficznych, takich jak: Poglady społeczno-pedagogiczne Aleksandra Kazimierza Patkowskiego (1890-1942) (Szczecin 1994), Chrześcijańska myśl wychowawcza Fryderyka Wilhelma Foerstera $i$ jej recepcja $w$ Polsce (Szczecin 1996), Janusz Jędrzejewicz - polityk i pedagog (1885-1951) (Szczecin 2004).

Szczególnie ważny nurt w działalności naukowo-badawczej Pani Profesor dotyczy dziejów Uniwersytetu Szczecińskiego, czego efektem są monografie: Rozwój Wyższej 
Szkoły Pedagogicznej w Szczecinie w latach 1968-1983 (Szczecin 1985), Droga do Uniwersytetu Szczecińskiego w opinii prasy centralnej i regionalnej w latach 1981-1985 (w 15. rocznice powstania uczelni) (Szczecin 2000), Człowiek-nauczyciel, uczony - Bolesław Sadaj (1908-1997) (Szczecin 2003), Studenci Uniwersytetu Szczecińskiego i ich organizacje w latach 1985-2000 (Szczecin 2007).

Ponadto Profesor Danuta Koźmian jest autorką hasła „Uniwersytet Szczeciński” zamieszczonego w Encyklopedii pedagogiki XXI wieku pod redakcją Tadeusza Pilcha, rozdziału pt. „Uniwersytet Szczeciński wczoraj i dziś” w Albumie Uniwersytetu Szczecińskiego (Szczecin 2001) oraz części pt. Uniwersytet Szczeciński - działalność naukowo-badawcza w latach 1985-2000 w pracy Środowisko naukowe Szczecina na progu XXI wieku (Szczecin 2000)3.

Doktor Robert Jankowski pracował w Zakładzie Historii Wychowania od początku jego istnienia, najpierw na stanowisku adiunkta, a od roku 2001 starszego wykładowcy. Jego zainteresowania badawcze dotyczyły historii i perspektyw szkolnictwa zawodowego, organizacji szkolnictwa morskiego na Pomorzu Zachodnim oraz zagadnień pedentologicznych w perspektywie krajowej i regionalnej. Zostało to uwidocznione między innymi w następujących artykułach i rozprawach: Nowe zadania i możliwości nauczyciela wobec potrzeb edukacji przyszłości, w: Pomiar edukacyjny jako kompetencje pedagogiczne, pod redakcją K. Wenty (Szczecin 2001), Ksztatcenie nauczycieli w sytuacji zmiany w oświacie, w: Reformy edukacyjne w Polsce, tradycje $i$ wspótczesność, pod redakcją I. Michalskiej i G. Michalskiego (Skierniewice 2001), Problemy budowy szkoty polskiej na Pomorzu Zachodnim w pracach Ogólnopolskiego Zjazdu Oświatowego w Łodzi w 1945 roku, w: Kongresy i Zjazdy Pedagogiczne w Polsce $i$ w Europie w XX wieku, pod redakcją A. Kicowskiej (Toruń 2001), Szkoły salezjańskie w Szczecinie, organizacja i rozwój, w: Szkolnictwo niepubliczne $w$ Polsce $i$ w Europie $w$ XX wieku, pod redakcją T. Jałmużny i W. Leżańskiej (Łódź 2002), Organizacja szkolnictwa morskiego na Pomorzu Zachodnim po drugiej wojnie światowej, w: Oświata, wychowanie i kultura fizyczna w rzeczywistości społeczno-politycznej Polski Ludowej (1945-1989), pod redakcją R. Grzybowskiego (Torun 2004), Kadra pedagogiczna szkolnictwa zawodowego na Pomorzu Zachodnim w latach 1945-1975, w: Polityka oświatowa w Polsce w XX wieku, pod redakcją I. Kość i E. Magiery (Szczecin 2008).

Doktor Ilona Kość rozpoczęła pracę w Zakładzie Historii Wychowania w 1993 r. Prowadziła zajęcia dydaktyczne z następujących przedmiotów: historia wychowania, pedagogika porównawcza, podstawy prawne i organizacyjne oświaty. Jej zainteresowania naukowe podejmują analizę zmian zachodzących na przestrzeni ostatnich lat w polskim systemie szkolnym, szczególnie jednak interesuje się przemianami dokonującymi się w szkolnictwie wyższym. Wielokrotnie ukazywała je przez pryzmat analizy komparatystycznej. W 2006 r. została wydana autorska książka pt. Przemiany systemu polskiej edukacji $w$ warunkach procesu europeizacji, podejmująca tematykę reformowania polskiej

\footnotetext{
${ }^{3}$ Robert Jankowski, Profesor Danuta Koźmian - uczona i mistrz dla kilku pokoleń nauczycieli na Pomorzu Zachodnim, w: Z dziejów oświaty polskiej. Księga Jubileuszowa dedykowana Profesor Danucie Koźmian, pod redakcją Ilony Kość i Elżbiety Magiery, Szczecin 2007, s. 15-17.
} 
oświaty, którą można uznać za wynik wielu procesów, w tym przede wszystkim procesu transformacji i europeizacji.

Do najbardziej reprezentatywnych pozycji w dorobku naukowym dr Ilony Kość należą: Europeizacja polskiej oświaty oceniana przez pryzmat równości szans edukacyjnych, w: Przemiany edukacyjne w Polsce $i$ na świecie a modele wychowania, redakcja W. Korzeniowska (Kraków 2001), Percepcja poglądów Ellen Key we współczesnym systemie oświatowo-wychowawczym w Szwecji, w: Dziecko $w$ rodzinie i społeczeństwie. Dzieje nowożytne, tom II, redakcja K. Jakubiak i W. Jamrożek (Bydgoszcz 2002), Kierunki polityki wsparcia społecznego podejmowanego wobec seniorów (na przykładzie miasta Calgary w prowincji Alberta w Kanadzie), współredakcja E. Zator, redakcja B. Kromolicka, B. Bugajska, K. Serdyńska (Szczecin 2007), Comparative reflection about volunteering (Komparatywne rozważania na temat wolontariatu), w: Socialna pedagogika, socjalna praca a socjalna andragogika - aktualne otazky teorie a praxe, redakcja A. Tokarova, T. Matulayova (Preśov 2008).

Doktor habilitowana Elżbieta Magiera została zatrudniona w Zakładzie Historii Wychowania na stanowisku asystenta w 1993 r. Po dwóch latach pracy został otwarty przewód doktorski, który zakończył się w 2000 r. obroną pracy doktorskiej, napisanej pod opieką Pani Profesor Danuty Koźmian na temat „Wychowanie państwowe i jego realizacja w szkolnictwie powszechnym Drugiej Rzeczypospolitej”.

W latach 1993-2012 realizowała zadania dydaktyczne na kierunku pedagogika. Wiodącym przedmiotem, który prowadziła w oparciu o autorski program kształcenia była najpierw historia wychowania, a potem historia myśli pedagogicznej, z której prowadziła w okresie asystentury ćwiczenia, a po doktoracie wykłady i ćwiczenia. Równolegle prawie przez cały okres pracy w zawodzie nauczyciela akademickiego prowadziła ćwiczenia i wykłady z pedagogiki porównawczej. W tym czasie realizowała również inne zajęcia dydaktyczne w trybie stacjonarnym i niestacjonarnym na jednolitych studiach magisterskich, studiach pierwszego i drugiego stopnia oraz na studiach podyplomowych, z takich przedmiotów, jak: teoria wychowania, pedagogika pracy, pedeutologia, zawód nauczyciela, zawód pedagoga-wychowawcy, podstawy prawne i organizacyjne oświaty, edukacja międzykulturowa, proseminarium. Po otrzymaniu w roku 2012 stopnia doktora habilitowanego realizuje zajęcia na studiach trzeciego stopnia: wykłady i seminarium doktoranckie. Od 2006 r. prowadzi seminaria licencjackie i magisterskie na studiach pierwszego i drugiego stopnia w trybie stacjonarnym i niestacjonarnym na kierunku pedagogika.

Zainteresowania naukowe dr hab. Elżbiety Magiery skupiają się wokół dziejów szkolnictwa i myśli pedagogicznej XX w. w Polsce, a zwłaszcza okresu międzywojennego, w którym koncentruje się na dwóch zasadniczych obszarach: wychowaniu państwowym i edukacji spółdzielczej. Ponadto w Jej dorobku zauważyć można dwa mniejsze obszary badawcze związane z zagadnieniami pedeutologicznymi w okresie międzywojennym i niektórymi aspektami historii edukacji w drugiej połowie XX w.

Pierwszym i najwcześniejszym obszarem zainteresowań naukowych dr hab. E. Magiery było wychowanie państwowe i jego różnorodne aspekty realizacji w szkolnictwie powszechnym w latach międzywojennych, któremu poświęciła ponad dwadzieścia arty- 
kułów i pracę zwartą pt. Wychowanie państwowe w szkolnictwie powszechnym Drugiej Rzeczypospolitej (Szczecin 2003).

Innym obszarem zainteresowań naukowych były zagadnienia pedeutologiczne związane z okresem międzywojennym. W kilku artykułach przedstawiono problematykę dotyczącą historycznych kontekstów edukacji nauczycieli jutra, zadań nauczycieli szkół powszechnych w wychowaniu państwowym w Drugiej Rzeczypospolitej oraz znaczeniu nauczycieli w rozwijaniu spółdzielczości w okresie międzywojennym. Tematyce pedentologicznej została poświęcona książka pt. Andrzej Sobczak (1905-1979). Nauczyciel i księgarz (Szczecin 2005).

Ważnym obszarem badań naukowych, dotychczas w niewielkim stopniu spenetrowanych przez historyków wychowania, jest edukacja spółdzielcza w Drugiej Rzeczypospolitej. Temu problemowi poświęcono kilkanaście artykułów i książkę pt. Spółdzielczość jako forma edukacji w szkolnictwie polskim Drugiej Rzeczypospolitej (1918-1939), (Szczecin 2011).

W dorobku naukowym dr hab. E. Magiery znajdują się trzy prace zwarte, cztery książki pod redakcją i około 70. artykułów z zakresu dziejów szkolnictwa i myśli pedagogicznej XX w., a zwłaszcza okresu międzywojennego. Do najważniejszych publikacji należą: Wychowanie państwowe w szkolnictwie powszechnym Drugiej Rzeczypospolitej (Szczecin 2003), Andrzej Sobczak (1905-1979). Nauczyciel i księgarz (Szczecin 2005), Spółdzielczość jako forma wychowania w szkolnictwie polskim Drugiej Rzeczypospolitej (1918-1939), (Szczecin 2011), Z dziejów oświaty polskiej. Księga Jubileuszowa dedykowana Profesor Danucie Koźmian, red. I Kość, E. Magiera (Szczecin 2007), Polityka oświatowa $w$ Polsce $w X X$ wieku. Historyczne tradycje $i$ wspótczesne odniesienia, red. I. Kość, E. Magiera (Szczecin 2008), Szkice z teorii i praktyki wychowania w Polsce $i$ w Norwegii w XX wieku, red. E. Magiera (Toruń 2010), Wokót wybranych twórców idei pedagogicznych u zarania $i$ w Drugiej Rzeczypospolitej, red. W. Andrukowicz, E. Magiera (Szczecin 2012).

Bardzo ważnym wydarzeniem w szesnastoletniej historii Zakładu był Jubileusz siedemdziesięciolecia Pani Prof. zw. dr hab. Danuty Koźmian, wybitnego historyka wychowania i twórcy ośrodka naukowego na ziemi szczecińskiej, zajmującego się badaniami nad dziejami szkolnictwa i myśli pedagogicznej. Uroczystość odbyła się 27 kwietnia 2006 r. w Instytucie Pedagogiki Uniwersytetu Szczecińskiego z udziałem władz Uniwersytetu Szczecińskiego, pracowników Instytutu Pedagogiki, najbliższej Rodziny Pani Profesor, władz Państwowej Wyższej Szkoły Zawodowej w Gorzowie Wielkopolskim oraz licznego grona studentów, seminarzystów i przyjaciół Pani Profesor. Spotkanie było okazją do wyrażenia szacunku, uznania i serdecznego podziękowania za kilkudziesięcioletnią pracę naukową i dydaktyczną, za wielki intelektualny i emocjonalny wpływ Pani Profesor Danuty Koźmian na społeczność akademicką i środowisko nauczycieli.

W całym okresie funkcjonowania Zakładu Historii Wychowania jego pracownicy utrzymywali stałą współpracę między innymi z Zakładem Historii Wychowania Uniwersytetu im. Adama Mickiewicza w Poznaniu, Katedrą Historii Wychowania i Pedeutologii Uniwersytetu Łódzkiego, Zakładem Historii Nauki, Oświaty i Wychowania Uniwersytetu Gdańskiego, Zakładem Historii Edukacji Uniwersytetu Wrocławskiego. 


\section{Działalność naukowo-dydaktyczna Katedry Historii Wychowania}

W 2008 r. po przejściu na emeryturę Pani Prof. zw. dr hab. Danuty Koźmian nastąpiły zmiany organizacyjne. Na podstawie decyzji Rady Wydziału Humanistycznego Uniwersytetu Szczecińskiego powołano Katedrę Historii Wychowania, a jej kierownikiem został dr hab. prof. US Wiesław Andrukowicz.

Profesor Wiesław Andrukowicz rozpoczął pracę jako nauczyciel akademicki w 1975 r. roku na stanowisku starszego asystenta w Zakładzie Dydaktyki Ogólnej w Wyższej Szkole Pedagogicznej w Szczecinie. W roku 1985 obronił rozprawę doktorską na Wydziale Nauk Społecznych Uniwersytetu im. Adama Mickiewicza w Poznaniu i uzyskał stopień doktora nauk humanistycznych w zakresie pedagogiki. W latach 1985-1986 pracował jako inspektor oświaty i wychowania w Dobrzanach. W latach 1986-1988 był zatrudniony jako adiunkt w Oddziale Doskonalenia Nauczycieli w Szczecinie. Od 1988 do 2008 r. pracował na stanowisku adiunkta w Zakładzie Dydaktyki Ogólnej Uniwersytetu Szczecińskiego. W roku 2007 uzyskał stopień doktora habilitowanego nauk humanistycznych w zakresie pedagogiki ogólnej ma Wydziale Pedagogiki i Psychologii Uniwersytetu Kazimierza Wielkiego w Bydgoszczy.

Zainteresowania naukowe dr hab. prof. US Wiesława Andrukowicza skupiają się wokół następujących obszarów badawczych: komplementarnych strategii poznania, synchronii i diachronii rozwoju i formowania człowieka, kompetencji lingwistycznych i komunikatywnych, historycznych i komparatystycznych źródeł pedagogiki, podstaw ontologicznych i epistemologicznych wychowania i kształcenia, pedagogiki filozoficznej i historii myśli pedagogicznej.

Osiągnięcia w pracy naukowo-badawczej Profesora Wiesława Andrukowicza mają swój wyraz w bogatym dorobku wydawniczym. Przed uzyskaniem stopnia naukowego doktora opublikował jedenaście książek (w tym 10 autorskich i 1 pod redakcją). Należą do nich m.in. Szlachetny pożytek. O filozoficznej pedagogice Bronisława Ferdynanda Trentowskiego (Szczecin 2006), Dydaktyka komplementarna (Warszawa 2004), Edukacja integralna (Kraków 2001), Teoria ksztatcenia integralnego (Gorzów Wielkopolski 2000). W tym samym okresie był autorem około stu artykułów naukowych i rozdziałów w książkach polskich i zagranicznych.

Po uzyskaniu stopnia doktora habilitowanego opublikował trzy książki: By dziecko było geniuszem. Wprowadzenie do edukacji komplementarnej (Kraków 2012), Bronistaw F. Trentowski, Chowanna, (Myśli wybrane) (Kraków 2010), Wokót wybranych twórców idei pedagogicznych u zarania $i$ w Drugiej Rzeczypospolitej, red. W. Andrukowicz, E. Magiera (Szczecin 2012). W tym samym okresie Profesor Wiesław Andrukowicz opublikował 23 artykuły naukowe i rozdziały w książkach.

W zakresie pracy dydaktycznej w Katedrze realizowane są zajęcia dydaktyczne z następujących przedmiotów: historia myśli pedagogicznej, pedagogika porównawcza, socjologia wychowania. Ponadto prowadzone są seminaria dyplomowe na studiach pierwszego i drugiego stopnia oraz seminaria doktorskie.

W ramach działalności naukowo-badawczej Katedry Historii Wychowania kontynuowane są badania nad dziejami szkolnictwa i myśli pedagogicznej w XX w., zapoczątko- 
wane przez pioniera i inicjatora szczecińskiej historii wychowania Panią Profesor Danutę Koźmian. Ponadto pojawił się znaczący dorobek Profesora Wiesława Andrukowicza w zakresie filozofii wychowania, o czym stanowią badania w ujęciu czysto historycznym, ale również adaptacyjnym nad pedagogiką filozoficzną Bronisława Ferdynanda Trentowskiego i Sergiusza Hessena.

Kolejnym ważnym obszarem badawczym realizowanym w Katedrze są zagadnienia spółdzielczości i samorządności szkolnej w Drugiej Rzeczypospolitej, których zwieńczeniem było uzyskanie na Wydziale Nauk Społecznych Uniwersytetu Gdańskiego w dniu 8 listopada 2012 r. przez dr Elżbietę Magierę stopnia naukowego doktora habilitowanego w dziedzinie nauk społecznych w zakresie pedagogiki, specjalność: historia wychowania.

Ważne miejsce w działalności naukowo-badawczej Katedry zajmuje problematyka edukacji w okresie Polski Ludowej, ze szczególnym uwzględnieniem działalności organizacji młodzieżowych, którą z powodzeniem realizuje dr Joanna Król. W Katedrze Historii Wychowania dr Joanna Król pracuje na stanowisku adiunkta od 2008 r. Do tego czasu była pracownikiem Zakładu Pedagogiki Ogólnej kierowanego przez nieżyjącego już prof. dr hab. Jerzego Materne. Związki naukowe dr Joanny Król z Katedrą Historii Wychowania (wcześniej funkcjonującą pod nazwą: Zakład Historii Wychowania) datują się już od 1995 r., to jest od faktu uczestnictwa w seminarium doktorskim prowadzonym przez prof. zw. dr hab. Danutę Koźmian. W roku 2003 na podstawie pracy doktorskiej pt. „Szkolnictwo średnie ogólnokształcące w województwie szczecińskim w latach 1945-1990”, Joanna Król uzyskała stopień doktora nauk humanistycznych w specjalności pedagogika.

Obszary badawcze dr Joanny Król oscylują wokół dziejów myśli i praktyki wychowawczej, ze szczególnym uwzględnieniem rozwoju oświaty polskiej w okresie Polski Ludowej. Zainteresowania naukowe dotyczą w szczególności: historii powojennych organizacji młodzieżowych, polityczno-społecznego aspektu funkcjonowania szkoły oraz rozwoju edukacji w wymiarze regionalnym.

Joanna Król jest autorką trzech monografii autorskich ${ }^{4}$ oraz kilkudziesięciu artykułów i rozdziałów w pracach zbiorowych. Do najważniejszych publikacji należą m.in. Refleksje o wychowaniu młodzieży szkót średnich ogólnokształcacych w latach 1948-1956, Potrzeba badań regionalnych-spojrzenie historyka oświaty, Model ojca i syna $w$ ideologii wychowawczej lat 1948-1956 w Polsce, Przejawy kultury organizacyjnej Zwiazku Młodzieży Polskiej (1948-1957) - wybrane aspekty5.

${ }^{4}$ Uchronić przed zapomnieniem - średnia szkoła ogólnokształcąca w województwie szczecińskim w latach 1945-1948, Szczecin 2005; Licea ogólnoksztatcąe w województwie szczecińskim w latach 1948-1961, Toruń 2009; To idzie młodość... Związek Młodzieży Polskiej w szkole średniej ogólnokształcącej w latach 1948-1957, Kraków 2011.

${ }_{5}^{5}$ Refleksje o wychowaniu młodzieży szkół średnich ogólnokształcących w latach 1948-1956, w: Przemiany edukacyjne $w$ Polsce i na świecie a modele wychowania, red. W. Korzeniowska, Kraków 2001; Potrzeba badań regionalnych - spojrzenie historyka oświaty, w: Z dziejów oświaty polskiej. Księga Jubileuszowa dedykowana Profesor Danucie Koźmian, red. I. Kość, E. Magiera, Szczecin 2007; Model ojca i syna w ideologii wychowawczej lat 1948-1956 w Polsce, w: Mężczyzna w rodzinie i społeczeństwie - ewolucja ról w kulturze polskiej i europejskiej, t. 2, red. E. Głowacka-Sobiech, J. Gulczyńska, Poznań 2010; Przejawy kultury organizacyjnej ZMP (1948-1957) - wybrane aspekty, „Kultura i Historia” 21/2012. 
Szereg z pozycji w dorobku naukowym dr Joanny Król jest pokłosiem uczestnictwa w konferencjach ogólnopolskich i międzynarodowych organizowanych przez różnorodne środowiska naukowe: pedagogów, historyków oraz filozofów. Uzupełnieniem aktywności naukowej dr Joanny Król jest Jej praca dydaktyczna. Obok seminariów licencjackich i magisterskich prowadzi zajęcia z historii myśli pedagogicznej, pedagogiki porównawczej oraz socjologii edukacji.

W roku 2013 w Katedrze Historii Wychowania pracowały następujące osoby: dr hab. prof. US Wiesław Andrukowicz, dr hab. Elżbieta Magiera, dr hab. prof. US Andrzej Sowiński, dr Robert Jankowski, dr Joanna Król, dr Justyna Nowotniak, mgr Maciej Sokołowski-Zgid. 